\section{JURNAL ABDIMAS

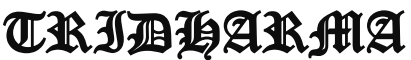

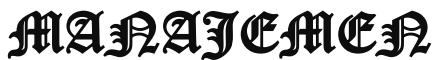

P-ISSN 2615-6849, E-ISSN 2622-3686

Jurnal ABDIMAS Vol. 1,No. 3,September 2020,Hal (56-62)

@ Prodi Manajemen Fakultas Ekonomi Universitas Pamulang

Email: abdimasjurnal.unpam@gmail.com Telp: (021) 741-2566

\title{
MENGEMBANGKAN POTENSI KARANG TARUNA MELALUI OPTIMALISASI ORGANISASI SEBAGAI UPAYA MENINGKATKAN PERAN PEMUDA DALAM MASYARAKAT
}

\author{
Herry Suherman, Kemas Vivi Andayani, Selvy Dwi Widiyanti, Andri Priadi, Agus \\ Dosen Ekonomi, Fakultas Ekonomi, Universitas Pamulang \\ Email : dosen01060@unpam.ac.id, dosen01342@unpam.ac.id, \\ dosen02468@unpam.ac.id, dosen02160@unpam.ac.id, dosen01365@unpam.ac.id
}

\begin{abstract}
ABSTRAK
Kegiatan pengabdian masyarakat dengan bentuk pendampingan kepada Karang Taruna bagi pembentukan organisasi Karang Taruna di wilayah RW 011 Kelurahan Pengasinan ini secara umum telah memenuhi target. Program kerja yang berkaitan dengan penataan kelembagaan dan peningkatan kompetensi Sumber Daya Manusia berjalan dengan efektif. Pengurus Karang Taruna yang terpilih semakin memahami akan pentingnya pelayanan kepada masyarakat dilingkungan RW 011 Kelurahan Pengasinan dan mampu untuk memberi pelayanan yang memuaskan kepada masyarakat pada umumnya di wilayah Kelurahan Pengasinan. Dari kelengkapan perangkat yang ada dan didukung oleh Sumber Daya Manusia muda yang kompeten, punya rasa tangung jawab dan disiplin yang tinggi cukup memadai, Pengurus Karang Taruna mampu untuk meningkatkan kemampuan dalam memberikan pelayanan kepada msyarakat secara optimal. Dari berbagai kelemahan sebagaimana yang dikemukakan pada latarbelakang masalah maka melalui program pemberdayaan ini dapat disimpulkan: 1. Terbentuknya pengurus Karang Taruna di lingkungan RW 011 Kelurahan Pengasinan, 2. Terbentunya draft Struktur Organisasi Karang Taruna di lingkungan RW 011 Kelurahan Pengasinan, 3. Terbentuknya draft dokumen AD/ART menjadi pedoman bagi Pengurus Karang Taruna untuk menggerakkan roda organisasi maupun arah pengembangan, 4. Penataan kelembagaan yang telah dilakukan dengan adanya kejelasan struktur dan pembagian tugas atau job deskripsi semakin menambah efektivitas dan efisiensi dalam pengelolaan organisasi, 5. Tersedianya media promosi berbasis IT menambah eksistensi Organisasi Karang Taruna dalam menjalankan kiprahnya di bidang pelayanan masyarakat.
\end{abstract}

\section{Kata Kunci : Pengabdian masyarakat, Karang Taruna, Opimalisasi Organisasi dan Peran Pemuda}

\begin{abstract}
ABSTRAC
Community service activities with the form of assistance to the Youth for the formation of a Youth organization in the region RW 011 Village Marinating this in general has to meet the target. The Program of work relating to institutional arrangement and increase the competence of Human Resources to run effectively.
\end{abstract}




\section{JURNAL ABDIMAS

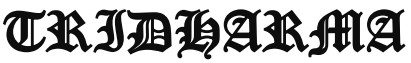

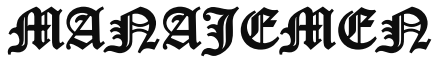

P-ISSN 2615-6849, E-ISSN 2622-3686

Jurnal ABDIMAS Vol. 1,No. 3,September 2020,Hal (56-62)

@ Prodi Manajemen Fakultas Ekonomi Universitas Pamulang

Email: abdimasjurnal.unpam@gmail.com Telp: (021) 741-2566

The board of Karang Taruna elected increasingly understand the importance of service to the community in the environment of $R W 011$ Village Salting and able to give a satisfactory service to the community at large in the Village of Marinating. From the completeness of the existing devices and supported by the young Human Resources who are competent, have a sense of responsibility and high discipline is quite adequate, the executive Board of the Youth were able to enhance the ability to provide services to the community optimally. From various drawbacks as mentioned in the background of the problems, then through this empowerment program can be concluded: 1. The formation of the board of Karang Taruna in the RW 011 Kelurahan Pengasinan, 2. Creating a draft Organizational Structure of the Youth in the RW 011 Kelurahan Pengasinan, 3. The formation of the draft document AD/ART to the guidelines for the management of Karang Taruna to move the wheels of the organization and the direction of development, 4. Institutional arrangement has been done with a lack of clarity in the structure and division of duties or job description further adds to the effectiveness and efficiency in the management of the organization, 5. The availability of the media promotion of IT-based add to the existence of the Youth Organization in running their work in the field of community service.

Keywords: Community service, Youth, Opimalisasi Organization and the Role of Youth

\section{PENDAHULUAN}

Saat ini banyak masyarakat yang tidak tahu tentang arti dan peran dari organisasi besar Karang Taruna. Walaupun ada yang tahu, itu hanya sebagian kecil saja, seperti Kepala Desa dan pejabat desa lainnya. Kadang masyarakat salah memahami Karang Taruna. Karang Taruna dipandang sebagai wadah untuk pemuda yang belum menikah saja, kegiatannya hanya berhubungan dengan olahraga dan kumpul bareng saja. Akibat dari ketidaktahuan ini, produktifitas Karang Taruna seakan-akan terlihat sempit dan kecil bahkan nyaris hilang. Hal ini sangat tidak sesuai dengan tujuan dibentuknya Karang Taruna tersebut.

Jika merujuk kepada AD/ART Karang Taruna, yang diatur dalam Peraturan Menteri Sosial Republik Indonsia No : 83/HUK/2005 ditetapkan di Jakarta pada tanggal 27 Juli 2005 yang ditandatangani oleh Menteri Sosial Republik Indonesia Bp. H. Bachtiar Chamsyah, SE, disebutkan bahwa "Karang Taruna adalah Organisasi Sosial wadah pengembangan generasi muda yang tumbuh dan berkembang atas dasar kesadaran dan tanggung jawab sosial dari, oleh dan untuk masyarakat terutama generasi muda di wilayah desa/kelurahan atau komunitas adat sederajat dan terutama bergerak dibidang usaha kesejahteraan sosial" (BAB 1 Pasal 1 tentang Ketentuan Umum). Kemudian dalam BAB 3 pasal 2 tentang tugas Karang Taruna menyebutkan bahwa: "Setiap Karang Taruna mempunyai tugas pokok secara bersama-sama dengan Pemerintah dan komponen masyarakat lainnya untuk menanggulangi berbagai masalah kesejahteraan sosial terutama yang dihadapi generasi muda, baik yang bersifat preventif, rehabilitatif maupun 


\section{JURNAL ABDIMAS

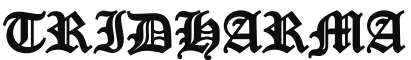

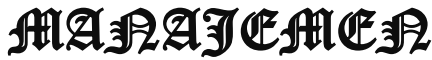

P-ISSN 2615-6849, E-ISSN 2622-3686

Jurnal ABDIMAS Vol. 1,No. 3,September 2020,Hal (56-62)

@ Prodi Manajemen Fakultas Ekonomi Universitas Pamulang

Email: abdimasjurnal.unpam@gmail.com Telp: (021) 741-2566 pengembangan potensi generasi muda di lingkungannya." Pengetian dan tugas Karang Taruna dalam AD/ART nya mmemberikan pencerahan kepada kita ternyata peran Karang Taruna bukan hanya masalah remaja saja, tetapi lebih dari itu, dan menyangkut kesejahteraan sosial. Karang Taruna memiliki tugas dan peran sebagai solusi dari masalah sosial, melibatkan anak-anak, remaja, pemuda dan orang tua.

Memaknai Karang Taruna dalam satu sudut pandang (untuk pemuda saja) sebenarnya tidak masalah. Akan tetapi akan berdampak pada produktivitas pemuda. Pemuda hanya akan peka terhadap masalah yang berkaitan dengan kepemudaan saja. Sehingga program pemberdayaan masyarakat terfokus pada pemuda pula, tidak kepada masalah sosisal secara umum. Pada akhirnya kita sebagai pemuda akan lupa bahwa masalah anak-anak lebih banyak, masalah orangtua harus di prioritaskan. Belum lagi kita berbicara masalah persatuan. Persatuan masyarakat desa akan terbangun jika kegiatan karang taruna melibatkan semua elemen masyarakat.

Mulai saat ini masyarakat perlu memahami urgensi tugas pokok Karang Taruna. Pemahaman tersebut bisa dilakukan dengan cara melakukan sosialisai oleh pemerintah desa atau yang berperan di bidang itu. Sosialisasi bisa disajikan dalam bentuk yang menarik seperti Ngobras (Ngobrol santai), Ngopi (Ngobrol Pemuda dan Pemudi), Nobar (Nonton Bareng) atau Mubar (Musyawarah Bareng). Setelah diberikan pemahaman, program Karang Taruna mesti diarahkan kerah pemecahan masalah sosial yang ada. Contoh Karang Taruna membuat Program Pendirian Desa Binaan Masyarakat Buta Aksara untuk masyarakat yang belum bisa membaca, Pendirian Taman Baca Anak untuk anak Desa, dan Pembinaan bekal Pra-nikah untuk para remaja dan lain-lain. Dengan demikian program kerja dan tujuan dibentuknya Karang Taruna memiliki relevansi dan diakui keberadaannya oleh pemerintah dan masyarakat.

Berdasarkan latar belakang masalah tersebut maka tim Pengabdian Kepada Masyarakat melakukan penyuluhan dengan judul "Mengembangkan Potensi Karang Taruna Melalui Optimalisasi Organisasi Sebagai Upaya Meningkatkan Peran Pemuda Dalam Masyarakat".

\section{METODE PELAKSANAAN}

Metode yang digunakan pada Pengabdian Kepada Masyarakat ini berupa ekspositori yaitu penyampaian materi secara verbal dan inquiry yaitu pembelajaran yang menekankan pada proses berpikir kreatif kritis dan analitis terkait optimalisasi organisasi terutama dalam bidang keuangan dan bisnis, yaitu meliputi :

1) Pendampingan.

Pada kegiatan ini dilakukan brain storming untuk membuka mindset tentang pentingnya Karang Taruna sebagai tempat mencetak pemuda yang madani dan kreatif yang mampu memberikan manfaat kepada masyarakat melalui peranan nya menjadi bagian dari pilar - pilar kesejahteraan sosial dan juga menjadi mitra kerja pemerintah yang produktif.

2) Penyuluhan

Aspek yang akan dikaji dalam kegiatan penyuluhan ini adalah faktor pembinaan dan pengembangan karang taruna dalam menciptakan solusi bagi dirinya sendiri dan masyarakat sekitar. Selain itu juga membahas tentang 


\section{JURNAL ABDIMAS

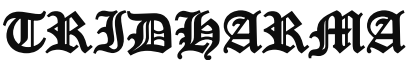

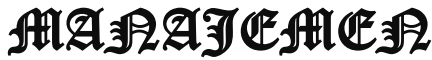

P-ISSN 2615-6849, E-ISSN 2622-3686

Jurnal ABDIMAS Vol. 1,No. 3,September 2020,Hal (56-62)

@ Prodi Manajemen Fakultas Ekonomi Universitas Pamulang

Email: abdimasjurnal.unpam@ gmail.com Telp: (021) 741-2566 bahaya penyalahgunaan narkotika, psikotropika zat aditif lainnya.

3) Praktek

Pada kegiatan ini akan diajarkan kegiatan yang dapat membuat struktur organisasi karang taruna, membuat nama organisasi dan juga AD/ART organisasi agar dapat mencakup seluruh aspek yang dibutuhkan.

4) Pelatihan

Kegiatan ini terkait masalah manajemen. Kegiatan ini dilakukan untuk menambah pengetahuan tentang pentingnya manajemen pembinaan Karang Taruna menjadi pemuda yang madani dan kreatif dan mampu memberikan manfaat kepada masyarakat

\section{HASIL DAN PEMBAHASAN}

Pelaksanaan pengabdian kepada masyarakat dengan metode pendampingan kelembagaan dan Sumber Daya Manusia dalam rangka pembentukan pengurus Karang Taruna RW 011 Kelurahan Pengasinan ini dilaksanakan pada tgl $08-10$ November 2019 dengan melakukan koordinasi program dengan stakeholder sekitar yang melibatkan Pengurus RW 011.

Bapak Edi Siswanto selaku Ketua RW 011 berserta jajarannya sangat mendukung pelaksanaan pengabdian kepada masyarakat ini dengan target dan luaran yang dihasilkan adalah program penataan kelembagaan dan Sumber Daya Manusia. Hasil keluaran pemberdayaan yang dihasilkan dari kegiatan ini antara lain adalah:

1. Terbentuknya pengurus Karang Taruna di lingkungan RW 011 Kelurahan Pengasinan.

2. Terbentunya draft Struktur Organisasi Karang Taruna di lingkungan RW 011 Kelurahan Pengasinan.

3. Terbentuknya draft dokumen AD/ART menjadi pedoman bagi Pengurus Karang Taruna untuk menggerakkan roda organisasi maupun arah pengembangan.

4. Penataan kelembagaan yang telah dilakukan dengan adanya kejelasan struktur dan pembagian tugas atau job deskripsi semakin menambah efektivitas dan efisiensi dalam pengelolaan organisasi.

5. Terbentuknya perencanaan strategis (renstra) dan uraian tugas (job description), bagi semua anggota dan pengurus dalam Karang Taruna RW 011 Kelurahan Pengasinan. Dengan adanya renstra diharapkan dapat dijadikan sebagai acuan bagi pengurus untuk menyusun program dan kegiatannya. Disamping itu dengan disusunnya job deskripsi seluruh pengurus dapat melakukan tugas sesuai bidangnya masing masing.

6. Tersedianya media promosi berbasis IT menambah eksistensi Organisasi Karang Taruna dalam menjalankan kiprahnya di bidang pelayanan masyarakat.

Pembahasan secara keseluruhan hasil yang diperoleh dan manfaat yang didapatkan dari kegiatan pengabdian kepada masyarakat ini sudah sesuai dengan target. Pengurus Karang Taruna yang terpilih mampu untuk mengembangkan diri menjadi penggerak organisasi yang profesional.

Sebagaimana disampikan dalam hasil dan manfaat tersebut di atas bahwa dengan adanya tempat sekretariat Karang Taruna RW 011 Kelurahan Pengasinan dapat berjalan dengan baik, fungsi administrasi mulai dari perencanaan sampai dengan evaluasi 


\section{JURNAL ABDIMAS

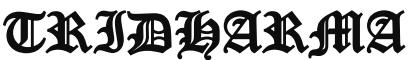

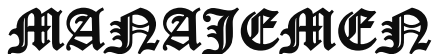

P-ISSN 2615-6849, E-ISSN 2622-3686

Jurnal ABDIMAS Vol. 1,No. 3,September 2020,Hal (56-62)

@Prodi Manajemen Fakultas Ekonomi Universitas Pamulang

Email: abdimasjurnal.unpam@gmail.com Telp: (021) 741-2566 kegiatan bisa terdokumentasi dengan baik.

Dari kelengkapan sekretariat tersebut organisasi perlu dipandu dengan berbagai dokumen tata kelola. Dengan adanya Rencana Strategis (Renstra) yang memberikan arah pengembangan bagi organisasi dan pembagian kerja secara lebih spesifik menjadi Karang Taruna mampu untuk bekerja secara lebih efektif dan efisien. Pembagian tugas yang rapi sesuai dengan kompetensinya menjadi metode kerja yang dipakai para pengurus dan anggota Karang Taruna RW 011 Kelurahan Pengasinan.

Dengan dilengkapinya dengan sarana Ruang Sekretariat dan dokumen tata kelola maka diperlukan pengembangan Sumber Daya manusia agar mampu menjalankan roda organisasi secara benar. Anggota dan pengurus Karang Taruna RW 011 yang kebanyakan pelajar SMP, SMA dan Mahasiswa bisa mendukung memberikan pelayanan kepada masyarakat sekitarnya secara maksimal dengan tenaga pelayanan yang handal. Peningkatan kompetensi Sumber Daya Manusia di bidang pelayanan jasa.

\section{KESIMPULAN DAN SARAN \\ Kesimpulan}

Kegiatan pengabdian masyarakat dengan bentuk pendampingan kepada Karang Taruna bagi pembentukan organisasi Karang Taruna di wilayah RW 011 Kelurahan Pengasinan ini secara umum telah memenuhi target.

Pengurus Karang Taruna yang terpilih semakin memahami akan pentingnya pelayanan kepada masyarakat dilingkungan RW 011 Kelurahan Pengasinan dan mampu untuk memberi pelayanan yang memuaskan kepada masyarakat pada umumnya di wilayah Kelurahan
Pengasinan.

\section{Saran}

Dari pelaksanaan kegiatan pengabdian kepada masyarakat tersebut masih ditemukan berbagai kendala yang perlu disempurnakan, oleh karena itu perlu diberikan saran baik kepada Pengurus Karang Taruna yang terpilih maupun Pejabat yang ada dilingkungan RW 011 Kelurahan Pengasinan berikut ini:

1. Pengurus RW 011 Kelurahan Pengasinan memberikan arahan regulasi yang jelas bagi Pengurus Karang Taruna terpilih untuk lebih meningkatkan semangat berorganisasi dalam jiwa Karang Taruna dilingkungan RW 011 Kelurahan Pengasinan.

2. Pengurus Karang Taruna yang terpilih harus menggerakkan roda organisasi harus terarah sesuai dengan dokumen tata kelola yang telah disusunnya.

3. Pengurus Karang Taruna harus mampu menjalankan keberlanjutan dari program sekrang dan masa mendatang sehingga meskipun program pengabdian masyarakat ini sudah selesai, pengurus Karang Taruna dapat berkembang sendiri.

4. Dengan melihat kondisi bahwa program ini belum sempurna maka ditahun mendatang perlu dilanjutkan dengan program lanjutan dan menekankan pada penguatan data dan pengembangan jejaring.

\section{Ucapan Terima Kasih}

Kami mengucapkan terimakasih kepada para pihak yang terlibat dalam kegiatan PKM ini, sehingga PKM dapat terlaksana dengan baik. 


\section{JURNAL ABDIMAS

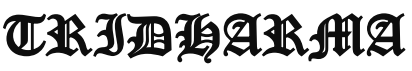

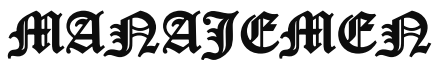

P-ISSN 2615-6849, E-ISSN 2622-3686

Jurnal ABDIMAS Vol. 1,No. 3,September 2020,Hal (56-62)

@Prodi Manajemen Fakultas Ekonomi Universitas Pamulang

Email: abdimasjurnal.unpam@gmail.com Telp: (021) 741-2566

\section{DAFTAR PUSTAKA}

Suharta, RB, 2009. Pengembangan Organisasi Kepemudaan. Jurusan Pendidikan Luar Sekolah, Fakultas Ilmu Pendidikan Universitas Negeri Yogyakarta.Yogyakarta.

Handayani, Annisa Yulia. Persepsi Pemuda terhadap Peranan Karang Taruna dalam Penanganan Masalah Sosial.2015. Jurnal penyuluhan Vol.11 No.1.

Pasaribu, V. L. D., Susanti, F., \& Hartuti, E. T. K. (2019). Memotivasi Siswa dan Siswi SMK Letris Indonesia di Dalam Menentukan Pilihan Untuk Melanjutkan Pendidikan Atau Bekerja Setelah Lulus Sekolah. Jurnal Pengabdian Dharma Laksana, 1(2), 161-172.

Pasaribu, V. L. D., Agrasadya, A., Shabrina, N., \& Krisnaldy, K. (2020). MENJADI ENTERPRENEUR MUDA YANG MEMILIKI JIWA LEADERSHIP UNTUK MENGHADAPI MASA DEPAN. $A b d i$ Laksana, 1(1).

Pasaribu, V. L. D., Elburdah, R. P., Sudarso, E., \& Fauziah, G. (2020). PENGGUNAAN MANAJEMEN WAKTU TERHADAP PENINGKATAN PRESTASI BELAJAR DI SMP ARAISIYAH. Jurnal ABDIMAS Tri Dharma Manajemen, 1(1).

Pasaribu, V. L. D., Sulaiman, S., Sutiman, S., Thaharudin, T., \& Purnomo, B. Y. (2020). PENGENALAN LETAK POSYANDU TERDEKAT DIKELURAHAN PISANGAN DENGAN MANAJEMEN PEMASARAN REVOLUSI 4.0 UNTUK MENINGKATKAN PENGETAHUAN MASYARAKAT LETAK DAN FUNGSI POSYANDU TERDEKAT PADA KELURAHAN PISANGAN. DEDIKASI PKM, 1(1), 105-110.

Pasaribu, V. L. D., Oktrima, B., Prabowo, B., Arianto, N., \& Haryoko, U. B. (2020). PROGAM PENDAMPINGAN DAN PENYELENGGARAAN PENDIDIKAN ANAK PADA USIA DINI TERHADAP PRESTASI BELAJAR DILINGKUNGAN RT 020 RW 009. KEL GIRI PENI. KEC WATES. YOGYAKARTA. JURNAL LOKABMAS KREATIF, 1(1), 71-75.
Peraturan menteri sosial Republik Indonesia NO: 77/HUK/2010. 2010. Pedoman Dasar Karang Taruna. Jakarta: Kemensos RI.

Jawa Pos. 2016. 5 Wilayah Rawan Narkoba.

https://www.pressreader.com/indon esia/jawapos/20160106/282720520945251. Diakses 3 Oktober 2017.

Permensos 83/HUK/2005 tentang Pedoman Dasar Karang Taruna UU Nomor 40 Th 2009 tentang Kepemudaan Permensos $77 \mathrm{Th}$ 2005 tentang Pedoman Dasar Karang Taruna.

\section{Dokumentasi}
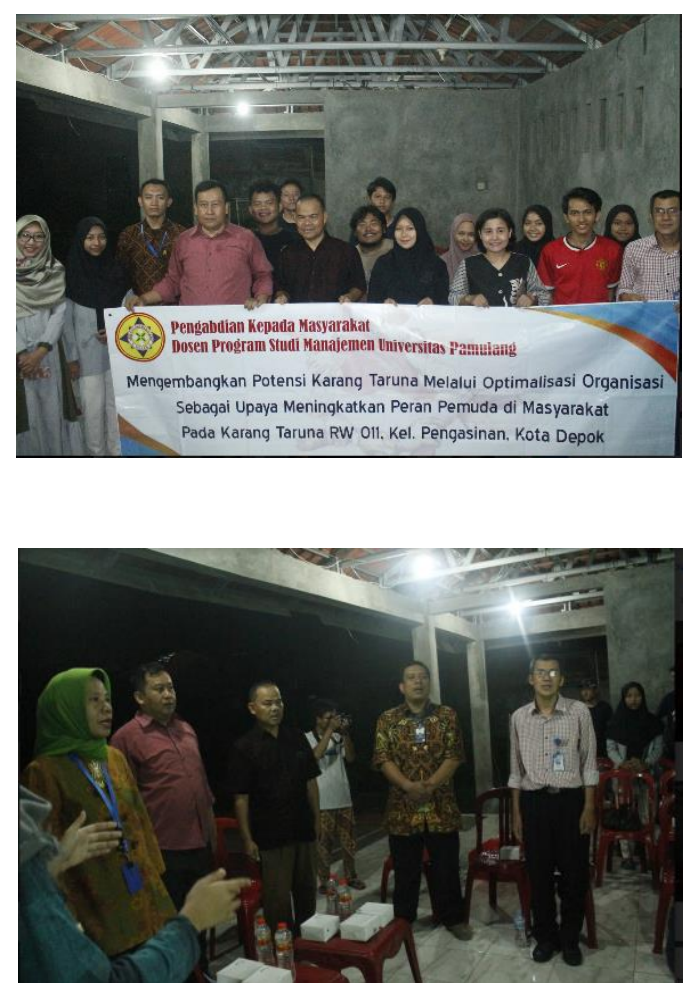


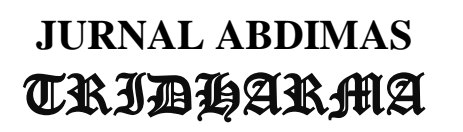

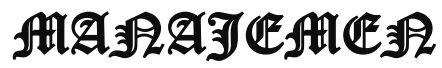

P-ISSN 2615-6849, E-ISSN 2622-3686

Jurnal ABDIMAS Vol. 1,No. 3,September 2020,Hal (56-62)

@ Prodi Manajemen Fakultas Ekonomi Universitas Pamulang

Email: abdimasjurnal.unpam@ gmail.com Telp: (021) 741-2566
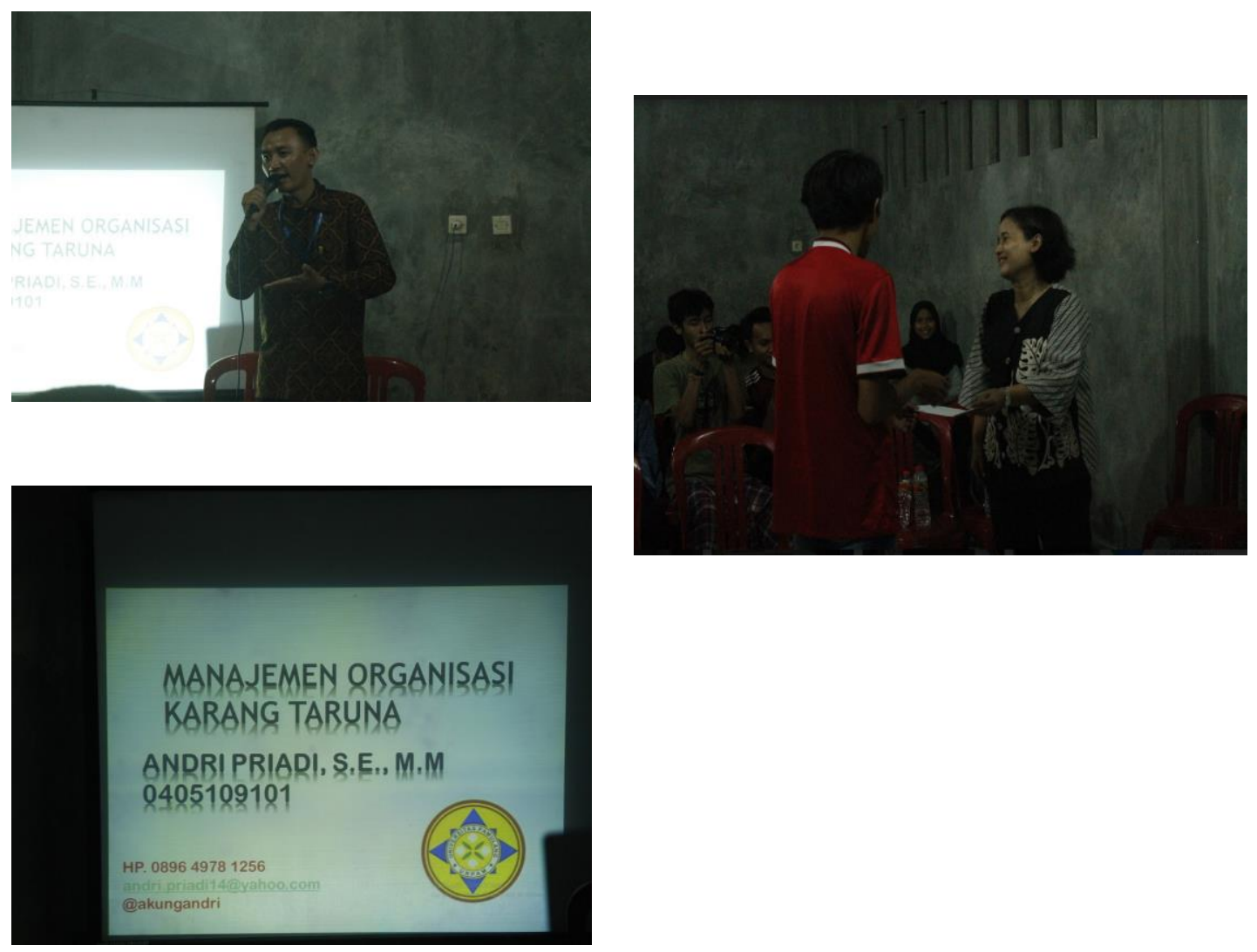

MANAJEMEN ORGANISASI

KARANG TARUNA

ANDRIPRIARI, S,E, M.M 0405109101 